\title{
Enfermedad de Chagas neonatal de transmisión vertical en países no endémicos. El uso de la PCR en el diagnóstico: ventajas sobre técnicas convencionales
}

\section{Congenital transmission of Chagas disease in non-endemic countries. The use of PCR for diagnosis: advantages over conventional techniques}

\author{
A. Martínez Ortiz' ${ }^{1}$ M. Herranz Aguirre', J. Guibert Valencia ${ }^{1}$ C. Ezpeleta Baquedano ${ }^{2}$
}

\section{Sr. Director:}

La enfermedad de Chagas está producida por el protozoo Trypanosoma cruzi y es una zoonosis endémica en el continente americano. La transmisión congénita de $T$. cruzi en áreas no endémicas está convirtiéndose en un problema emergente de salud pública. Desde 1980 un gran número de personas han emigrado de zonas endémicas de enfermedad de Chagas a nuestro país ${ }^{1}$. Según los datos del Instituto Nacional de Estadística el 13,6\% de la población española es inmigrante, siendo casi la mitad de ella de origen latinoamericano. Bolivia es el país con mayor prevalencia de la enfermedad de Chagas descrito, con más de 3 millones de población en riesgo ${ }^{2}$. Se han realizado escasos estudios para describir la seroprevalencia de la enfermedad de Chagas en áreas no endémicas en mujeres embarazadas inmigrantes procedentes de Latinoamérica. Tres de estos estudios se realizaron en España ${ }^{3}$. Los valores de prevalencia observados se encuentran entre 3,5 y $9,7 \%$, aunque si se analizan únicamente mujeres procedentes de Bolivia, aumenta hasta $16,6-27,7 \%^{4}$.
A continuación, describimos el caso de un neonato varón de 37 semanas de gestación que presenta a las pocas horas de vida fiebre, ictericia e hipoglucemia. Su peso, talla y perímetro cefálico se encuentran en percentiles normales. En la exploración física presenta irritabilidad, ictericia y petequias, abdomen distendido con hepatomegalia y esplenomegalia de $7 \mathrm{~cm}$ (Fig. 1). En la analítica de sangre destaca: anemia, trombopenia, coagulopatía, colestasis e hipergammaglobulinemia (IgM $348 \mathrm{mg} / \mathrm{dL}$ e IgG $1860 \mathrm{mg} / \mathrm{dL}$ ). El análisis bioquímico del líquido cefalorraquídeo es normal salvo leve hiperproteinorraquia (Eritrocitos: 1.920 /mm3, Leucocitos: 51 /mm3, Mononucleares: $90 \%$, Polinucleares: $10 \%$, Glucosa: $32 \mathrm{mg} / \mathrm{dL}$, Proteína: 2,48 g/L). La ecografía abdominal revela gran esplenomegalia que produce desplazamiento medial del riñón izquierdo y aumento del tamaño de la suprarrenal izquierda. La ecocardiografía y la ecografía cerebral son normales, así como el fondo de ojo, los potenciales auditivos y visuales. Ante la sospecha de infección congénita se realiza estudio básico infeccioso incluyendo las siguientes determinaciones: Citomegalovirus Ig $\mathrm{G}$ (positivo) con Ig M y
1. Servicio de Pediatría. Complejo Hospitalario de Navarra. Pamplona.

2. Servicio de Microbiología Clínica. Complejo Hospitalario de Navarra. Pamplona.

Recepción: 24 de agosto de 2012

Aceptación provisional: 2 de octubre de 2012

Aceptación definitiva: 6 de noviembre de 2012

\author{
Correspondencia: \\ Alba Martínez Ortiz \\ Servicio de Pediatría \\ Complejo Hospitalario de Navarra \\ C/Irunlarrea, 4 \\ 31008 Pamplona \\ E-mail: albamtzortiz@hotmail.com
}


PCR negativas, Ac anti VIH negativo, Herpes simplex Tipo I (Ig G positivo e Ig M negativos) y tipo 2 (IgG/M negativos), Toxoplasma Ig G-Ig M negativos; RPR y Ac treponémicos totales-CLIA negativos, Epstein Barr IgG-IgM negativos, Ac anti-Parvovirus Ig G-M negativos. Como hallazgo casual encontramos una IgM y una IgG ambas positivas para varicela habiendo pasado la madre la varicela anteriormente con PCR de varicela del niño negativo. Dada la procedencia materna de área endémica de enfermedad de Chagas (Ecuador) se realizan determinaciones serológicas para Trypanosoma cruzi mediante inmunofluorescencia indirecta (IFI) y quimioluminiscencia (QLIA) en la madre con resultado positivo. Así mismo resultan positivas en el niño, en el que además existe una positividad serólogica (IFI 1/64, QLIA positiva) confirmada para Trypanosoma cruzi con PCR positiva. No se puede objetivar la visión directa del parásito por dificultades técnicas. Al cuarto día de vida se inicia tratamiento con benznidazol (10 mg/kg/día). La evolución clínica y analítica es favorable, con reducción de la hepatoesplenomegalia en un mes y normalización de trastornos hematológicos. Tras una semana de tratamiento se negativiza la PCR de Trypanosoma cruzi. Se mantiene el tratamiento durante 2 meses, en los que el niño presenta un estancamiento ponderal que se resuelve al finalizar el tratamiento. Los resultados de las pruebas serológicas a los 16 meses son satisfactorios, con negativización serológica por IFI $<1 / 40$ aunque persiste serología por quimoluminiscencia positiva.

La transmisión vertical de la enfermedad de Chagas o tripanosomiasis americana ocurre en el 2 al $6 \%$ de las pacientes; el $90 \%$ de los neonatos infectados están asintomáticos ${ }^{5}$. La hepatoesplenomegalia es el signo más frecuente presente en los casos congénitos sintomáticos. No parece que produzca anomalías en el desarrollo fetal, si bien sí pueden producirse abortos o muerte fetal. Los signos clínicos más frecuentes son: prematuridad, bajo peso al nacer, ictericia, fiebre, edemas, anasarca, petequias y miocarditis ${ }^{6}$.

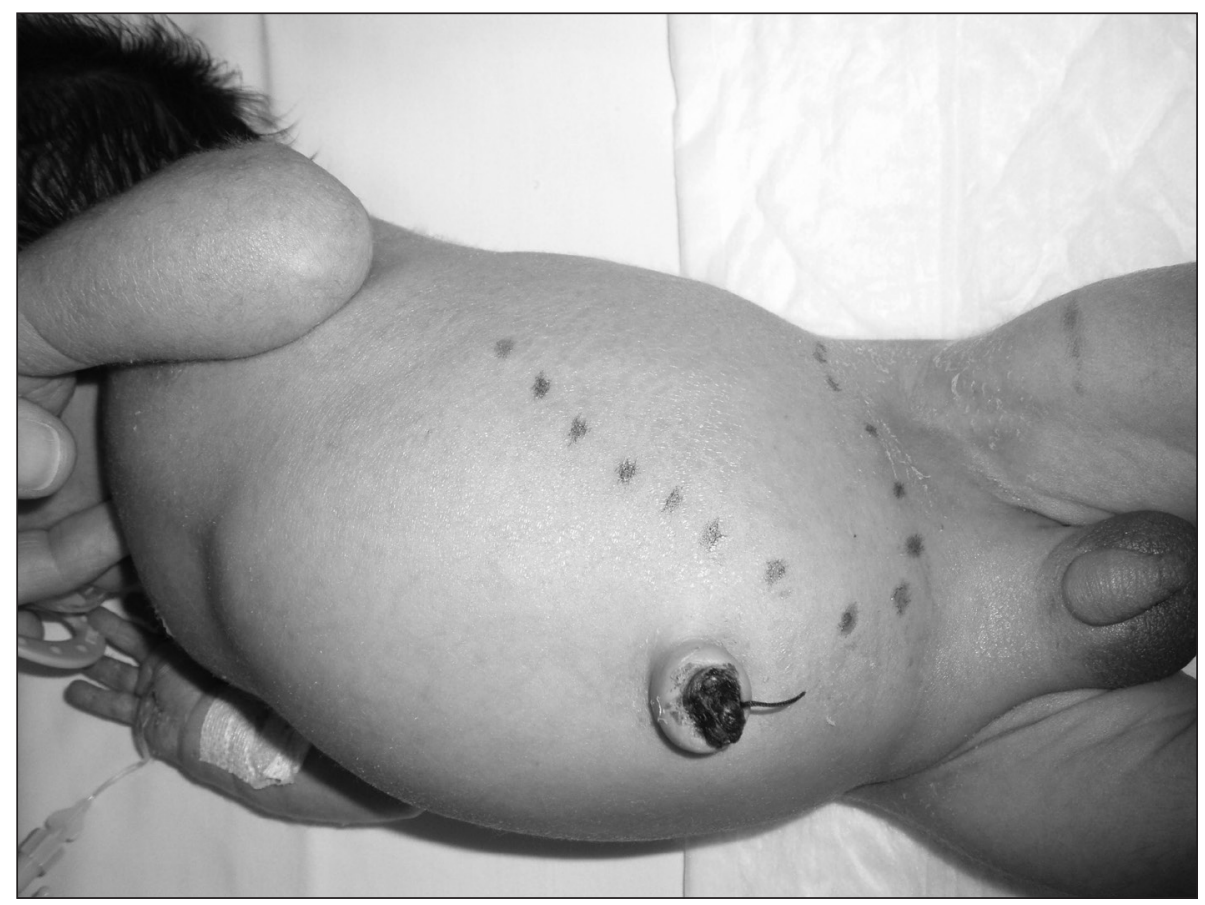

Figura 1. Exploración física al nacimiento: gran esplenomegalia de $7 \mathrm{~cm}$. 
Nuestro paciente presentaba una forma sintomática a pesar de haber nacido en un área no endémica. Rehistoriando a la madre refería haber realizado un viaje a zona endémica en el primer trimestre del embarazo. Esto aumenta la probabilidad de formas sintomáticas de infección congénita.

Para el diagnóstico de enfermedad de Chagas deben de cumplirse dos de los siguientes criterios, siendo el primero obligatorio $^{7}$ :

- Niño hijo de madre seropositiva para T. cruzi por dos métodos distintos;

- PCR positiva o detección del parásito en sangre del recién nacido al nacimiento o durante los primeros meses de seguimiento;

- Detección de anticuerpos anti-T. cruzi (IgG) en el niño a partir de los 9 meses de edad (los anticuerpos maternos ya deberían haber desaparecido)
El mayor inconveniente de las técnicas directas es que requieren cierta experiencia del examinador y material específico. Actualmente se ha demostrado la superioridad de la PCR respecto a la visualización directa del parásito en zonas no endémicas. El diagnóstico en la fase aguda es de extrema importancia debido a la alta eficacia del tratamiento ${ }^{8,9}$.

Se ha demostrado costo-efectivo realizar el cribado de enfermedad de Chagas en gestantes procedentes de áreas endémicas. Proponemos un protocolo de cribado en todas aquellas embarazadas inmigrantes procedentes de áreas endémicas, que incluya la realización de estudio serológico a las madres (dos técnicas serológicas diferentes positivas) ${ }^{10}$. Si éstas son positivas se debe realizar PCR/Micrométodo al recién nacido para T. cruzi. A partir de 9 meses de vida se podrá realizar estudio/seguimiento serológico (Tabla 1).

Tabla 1. Recomendaciones para el control de la transmisión vertical de la enfermedad de Chagas.

\begin{tabular}{l|l}
\hline Mujer embarazada & $\begin{array}{l}\text { Test serológico convencional (ELISA/Quimioluminiscencia en plasma o suero) + } \\
\text { confirmación con otro test convencional (generalmente IFI) }\end{array}$ \\
\hline $\begin{array}{l}\text { Recién nacido (sólo en caso } \\
\text { de madre infectada) }\end{array}$ & $\begin{array}{c}\text { Descartar transmisión vertical mediante: } \\
\quad \text { PCR / Visualización directa-Micrométodo } \\
\quad<9^{\circ} \text { mes: Serología }\end{array}$ \\
& $\begin{array}{l}\text { Criterio de curación es la negativización de la serología en los controles postra- } \\
\text { tamiento. }\end{array}$ \\
\hline
\end{tabular}

\section{BIBLIOGRAFÍA}

1. Schmunis GA, Yadon ZE. Chagas disease: a Latin American health problem becoming a world health problem. Acta Trop 2010; 115: $14-21$.

2. Brutus L, Schneider D, Postigo J, Romero M, Santalla J, Chippaux JP. Congenital Chagas disease: diagnostic and clinical aspects in an area without vectorial transmission, Bermejo, Bolivia. Acta Trop 2008; 106: 195-199.

3. Muñoz J, Coll O, Juncosa T, Vergés M, Del Pino M, Fumado V et al. Prevalence and vertical transmission of Trypanosoma cruzi infection among pregnant Latin American women attending 2 maternity clinics in Barcelona, Spain. Clin Infect Dis 2009; 48: 1736-1740.
4. Oliveira I, Torrico F, Muñoz J, Gaston J. Congenital transmission of Chagas disease: a clinical approach. Expert Rev Anti Infect Ther 2010; 8: 945-956.

5. Moya P, Basso B, Moretti E. Congenital Chagas disease in Cordoba, Argentina: epidemiological, clinical, diagnostic, and therapeutic aspects. Experience of 30 years of follow up. Rev Soc Bras Med Trop 2005; 38 (Suppl. 2): 33-40.

6. Muñoz Casas del Valle P, Thiermann E, Atias M, AcEvedo CS. Enfermedad de Chagas congenital sintomática en recién nacidos y lactantes. Rev Chil Pediatr 1992; 63: 196-202.

7. Yves C.; Torric F. Congenital infection with Trypanosoma cruzi: froma mechanisms of transmission to strategies for diagnosis and control. Rev Soc Bras Med Trop 2003; 36: 767-771. 
8. GonzÁlez-Granado LI, Guillen-Fiel G, Rojo-CoNEJO P. In nonendemic areas, is microscopy better than polymerase chain reaction for diagnosis of congenital Chagas disease? Clin Infect Dis 2010; 50: 279-280.

9. González-Granado LI, Rojo-Conejo P, Ruiz-Contreras J, GonzÁlez-Tomé MI. Chagas disease travels to Europe. Lancet 2009; 373: 2025.
10. Martínez Ortiz A, González Granado L. I, GonzÁlez-Tomé M.I. Tripanosomiasis Americana (enfermedad de Chagas). Guía-ABE_Tripanosomiasis americana (enfermedad de Chagas) (v.1/2011) (fecha de última actualización web: 21-mar-2012). Disponible en: http:// www.guia-abe.es/temas-clinicos-tripanosomiasis-americana-(enfermedad-de-chagas) 